\section{Professor William Cavazza - A Profile}

\section{IUGS Treasurer}

William Cavazza obtained a BSc in Geological Sciences in 1983, summa cum laude, from the Alma Mater Studiorum, University of Bologna. His thesis involved field mapping in a controversial late Palaeozoic portion of the Carnic Alps, and resulted in the

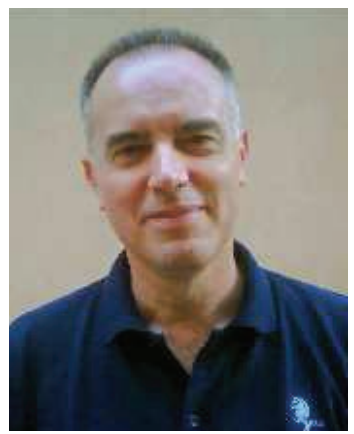

recognition of the significant effects of the Hercynian orogeny in this area. Supported by grants from the Italian Ministry of Education, Los Alamos National Laboratories, and the industrial sector, William then moved to the United States where he obtained an MSc in geology (1985) and a PhD in geology (1989) from the University of California, Los Angeles (UCLA). His MSc research focused on sediment provenance and dispersal in the Miocene Española rift basin of New Mexico. His $\mathrm{PhD}$ dissertation dealt with the sedimentary basin analysis of the Ionian forearc basin of southern Italy. Both projects were supervised by Prof. Raymond V. Ingersoll. During his PhD years at UCLA he was involved in other research projects, resulting in several papers on Laramide syntectonic sedimentation in Montana, supradetachment sedimentation in the Mojave Desert, and the palaeogeography of the Rio Grande rift.

While still studying for his $\mathrm{PhD}$, William was hired as a lecturer at the University of Bologna. This marked the beginning of a longstanding interest in the geological evolution of the Mediterranean region. A vigorous research program in the area was initiated in 1989, including the award of two NATO Cooperative Research Grants (1991-1994) with Canadian and American institutions.

From 1994 to 1999 he was a leader together with Alastair Robertson and Peter Ziegler - of IGCP Project no.369 "Comparative Evolution of Peritethyan Rift Basins", whose goal was the integrated geologicalgeophysical study of rift/wrench basins located along the northern and southern
Tethyan margins and on the directly adjacent platforms. More than 200 researchers from thirty-six countries took part in the project. IGCP 369 summarized vast and heterogeneous datasets from several sources, stimulated new research to fill the gaps, and produced for the general international reader a modern and homogeneous synthesis of the state of the knowledge on the subject. The two major end products of IGCP 369 were (i) a large memoir published by the Muséum National d'Histoire Naturelle in Paris containing the main geological/geophysical characteristics of a number of peritethyan rift/wrench basins and passive margins, and (ii) a paleotectonic atlas of the peritethyan region published by the European Geophysical Union as a CD-ROM containing more than 200 new paleotectonic-paleoenvironmental maps covering the time span from the late Paleozoic to the Holocene.

In 1998 William joined the recently founded University of Basilicata (Potenza) in southern Italy as an Associate Professor. He stayed in Potenza for four years during which he held a number of scientific, teaching, and managing capacities, leading to the foundation of both the new Department of Geological Sciences and the Ph.D. Program in Geology.

From 2001 to 2004 he was a member of the Organizing Committee of the 32nd International Geological Congress in Florence, with the task to chair the activity of the Mediterranean Consortium, an association of thirty-one Mediterranean and nearby countries, which stimulated the submission of proposals for scientific sessions, short courses, workshops and fieldtrips from their national Earth sciences communities. The Mediterranean Consortium also generated the TRANSMED Project, a scientific research program aimed at developing a number of transects depicting the lithospheric and mantle structure across selected, representative regions of the Mediterranean domain and adjoining areas. This was accomplished integrating surface geology, seismic profiles and mantle tomography, both on land and at sea. The goal was to provide the international geoscientific community with the first supranational overview of the geological and geophysical structure of the complex Mediterranean domain. On the occasion of the Florence congress the main results of this project were released by Springer Verlag as the TRANSMED Atlas (edited jointly with F. Roure, W. Spakman, G.M. Stampfli, and P.A. Ziegler), which remains a standard reference for the Mediterranean region.

In 2002 William was appointed Professor of Sedimentology and Stratigraphy at the University of Bologna. At this stage, he began a new line of research focused on lowtemperature thermochronology [apatite fission tracks and (U-Th)/He] for basin analysis and the study of mountain-building processes. These methods were applied in the Alps (Simplon and Alpine Corsica), the Chilean Andes, and in several locations across Asia Minor.

A member of the Italian IUGS National Committee and Chair of the Italian IGCP National Committee, William was instrumental in stimulating a substantial improvement of the Italian participation in this effective international IUGS-UNESCO scientific programme. William's interest in all things IGCP culminated with his appointment as member (2005-2007) and chair (2008) of the IGCP Scientific Board, a position from which he resigned upon his election as IUGS Treasurer during the $33^{\text {rd }}$ International Geological Congress in Oslo.

William is a member of a range of learned and professional societies and in 2004 was elected a Fellow of the Geological Society of America. He is currently Associate Editor of Basin Research (Oxford), Journal of Sedimentary Research (Tulsa), Italian Journal of Geosciences (Rome), and Geologica Acta (Barcelona).

A curious mind and a keen advocate of multidisciplinary studies, William has published four books and over 50 papers in international journals on varied topics ranging from low-temperature thermochronology to strontium-isotope chronostratigraphy, from Mediterranean palaeogeography to hydrological models for carbonate concretioning. An avid traveller open to cooperation and new ideas, he likes the notion of synthesizing geological and geophysical data across political boundaries. He has also cooperated with the industrial sector, including scientific consulting for oil and mining companies.

William lives in downtown Bologna with his wife Elisabetta and daughter Ottavia who put up patiently with his presence and absence alike.

by Prof. Gian Battista Vai,

Director, Geological Museum "G. Capellini”, University of Bologna 